\title{
5-6 Yaş Grubu İçin Geliştirilen Aile Katılımlı Farklılıklara Saygı Programı'nın Çocukların Farklılıklara Saygı Düzeyine Etkisinin İncelenmesi
}

\author{
Özgül Polat ${ }^{1}$, Tuba Özkabak-Yıldız ${ }^{1}$ \\ ${ }^{I}$ Temel Eğitim Bölümü, Eğitim Fakültesi, Marmara Üniversitesi, İstanbul, Türkiye
}

Sorumlu Yazar: Tuba Özkabak-Y1ldız, tubaozkabak@hotmail.com

Makale Türü: Araştırma Makalesi

Kaynak Gösterimi: Polat, Ö., \& Özkabak-Yıldız, T. (2018). 5-6 yaş grubu için geliştirilen Aile Katılımlı Farklılıklara Saygı Programı'nın çocukların farklılıklara saygı düzeyine etkisinin incelenmesi. Eğitimde Kuram ve Uygulama, 14(4), 389-403. doi: $10.17244 /$ eku.466812

\section{The Effects of Respect for Diversity Program with Family Involvement on 5 and 6 Year Old Children's Respect for Diversity}

\author{
Özgül Polat ${ }^{1}$, Tuba Özkabak-Yıldız \\ ${ }^{I}$ Department of Elementary Education, Faculty of Education, Marmara University, Istanbul, Turkey
}

Corresponding Author: Tuba Özkabak-Yıldız, tubaozkabak@hotmail.com

Article Type: Research Article

To Cite This Article: Polat, Ö., \& Özkabak-Yıldız, T. (2018). 5-6 yaş grubu için geliştirilen Aile Katılımlı Farklılıklara Saygı Programı'nın çocukların farklılıklara saygı düzeyine etkisinin incelenmesi. Eğitimde Kuram ve Uygulama, 14(4), 389-403. doi: $10.17244 /$ eku.466812 
2018, 14(4), 389-403

\title{
5-6 Yaş Grubu İçin Geliştirilen Aile Katılımlı Farklılıklara Saygı Programı'nın Çocukların Farklılıklara Saygı Düzeyine Etkisinin İncelenmesi
}

\author{
Özgül Polat ${ }^{1}$, Tuba Özkabak-Yıldız ${ }^{1}$ \\ ${ }^{1}$ Temel Eğitim Bölümü, Eğitim Fakültesi, Marmara Üniversitesi, İstanbul, Türkiye \\ ORCID: http://orcid.org/0000-0001-7426-5771 \\ ORCID: http://orcid.org/0000-0002-7308-2444
}

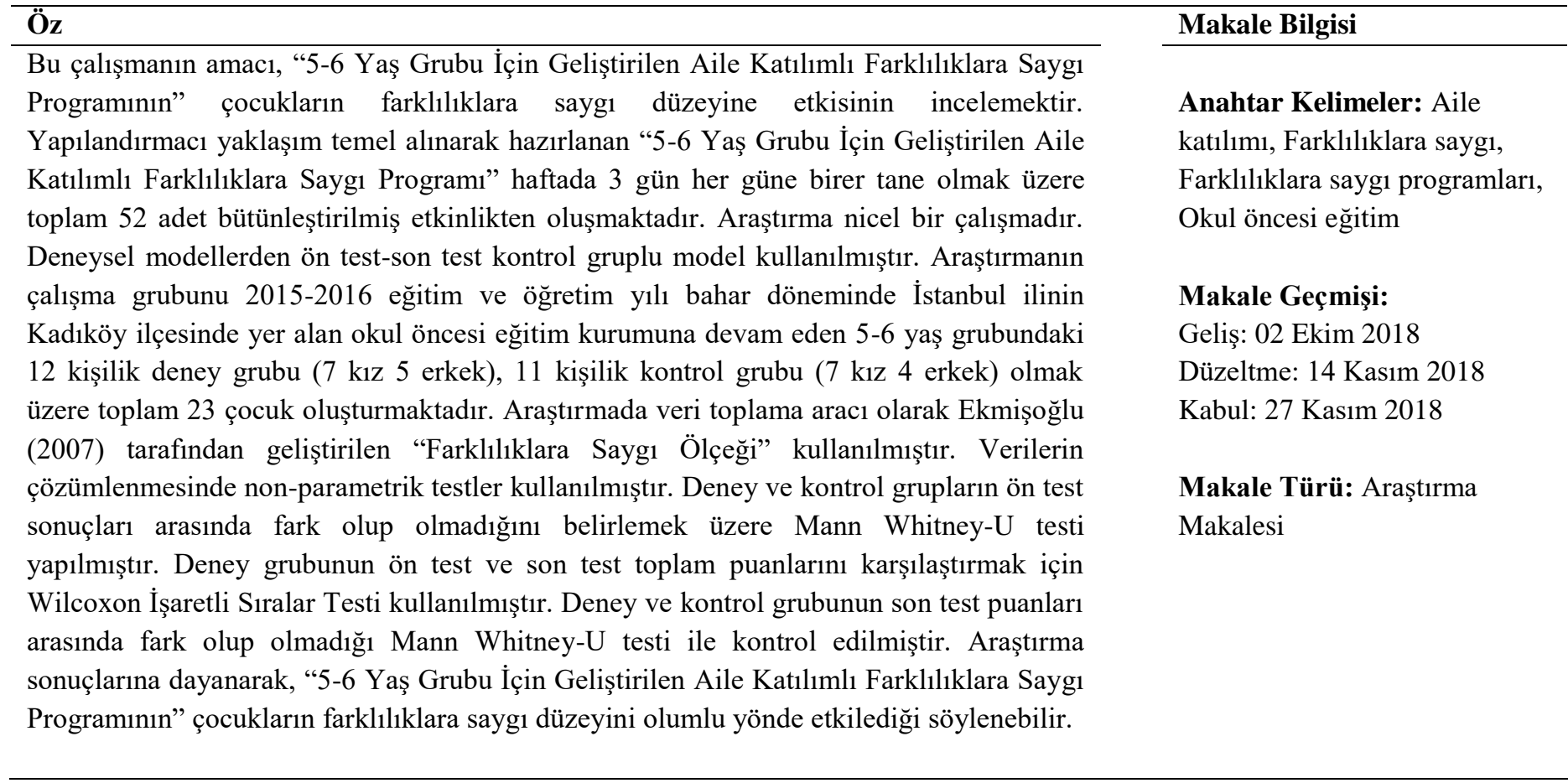




\title{
The Effects of Respect for Diversity Program with Family Involvement on 5 and 6 Year Old Children Respect for Diversity
}

\footnotetext{
Abstract

The main aim of this study is to examine the effect of Respect for Diversity Program with Family Involvement developed for the age group of 5-6 years on children's level of respect for diversity. Prepared based on a constructivist approach; "Respect for Diversity Program with Family Involvement Developed for the Age Group of 5-6 Years" consists of a total of 52 integrated activities, each of them implemented for 3 days a week. The study is a quantitative study. A model with a pretest-posttest control group, which is among the experimental models, was used in the study. The study group consisted of a total of 23 children; 12 in the experimental group ( 7 girls, 5 boys) and 11 in the control group ( 7 girls, 4 boys) in the age group of 5-6 years attending preschool education in Kadiköy, İstanbul in the spring term of the school year of 2015-2016. The "Scale of Respect for Diversity" developed by Ekmişoğlu (2007) was used in the research. Non-parametric tests were used in the analysis of the data. The Mann Whitney $U$ test was employed to determine whether there was a difference between the pre-test results of the experimental and control groups. The Wilcoxon Signed Sequence Test was used to compare the pre-test and post-test total scores of the experimental group. The difference between the post-test scores of the experimental and control groups was checked by the Mann-Whitney U test. On the grounds of the study results, it is possible to state that the "Respect for FamilyAttended Diversity Curriculum Developed for the Age Group of 5-6 Years" affects children's levels of respect for diversity positively.
}

\author{
Article Info \\ Keywords: Preschool \\ education, Respect for \\ diversity, Respect for \\ diversity programs, Family \\ involvement \\ Article History: \\ Received: 02 October 2018 \\ Revised: 14 November 2018 \\ Accepted: 27 November 2018 \\ Article Type: Research Article
}




\section{Giriş}

Okul öncesi dönem beyin gelişiminin en yoğun ve en hızlı olduğu dönemdir. Bu dönemde uzun yıllardır yapılan araştırmalar çocukların karşılaştıkları farklı çevre uyaranlarının zengin ve kaliteli olması ile çocuğun gelişimi arasında pozitif bir ilişki olduğunu göstermektedir. Çocuklar, gelişimleri sırasında karşılaştıkları çevreye nasıl uyum sağlayacaklarını öğrenmeye hazır bir şekilde dünyaya gelirler (Aamodt \& Wang, 2013). Bu nedenle çocuğun bilişsel, motor, dil, sosyal ve duygusal gelişimi için oluşturulan zemin güçlüdür. Özellikle okul öncesi dönem olarak adlandırılan hayatın ilk altı yılında çocuklar çok hızlı büyürler ve bu gelişim alanlarında şaşırtıcı bir hızla yetkinleşirler (Milli Eğitim Bakanlığı [MEB], 2013; Öztürk, Şahin \& Mercan, 2010). Bu dönemde çocukların karşılaştıkları farklı çevre uyaranları ne denli zengin ve kaliteli olursa çocuğun gelişimi de o nedenle hızlı ve sağlıklı olacaktır. Bu kapsamda çevre, çocuğun gelişimini ve öğrenme motivasyonunu derinden etkiler (MEB, 2013).

Çocuk bir aileye doğar ve kurumsal okul öncesi eğitime başlayana kadar burada büyür ve gelişir. Aile çocuğun gelişim ve eğitiminde çok önemli bir yere sahiptir. Her insan belli bir kapasiteyle dünyaya gelir. Öyle ki bireyin sahip olduğu kapasitenin tam olarak kullanılmasında kalıtsal olarak getirilen yeterliklerin yanı sıra ailenin sahip olduğu sosyal, kültürel, ekonomik düzeyin ve çocuklara sunulan çevrenin de çok önemli bir yeri vardır. Erken çocukluk yılları boyunca anne-babalar, günlük yaşam içinde çocukların araştırması, çevreyle aktif etkileşim içine girmesi ve gözlemler yaparak öğrenmesi için sonsuz olanaklar sunarlar (Gürşimşek, 2003).

Çocuğun ilk karşılaştığı çevre ailesidir. Birey anne ve babanın sadece genetik özelliklerinden değil, doğduğu andan itibaren ailenin sahip olduğu sosyo-kültürel ve ekonomik gibi faktörlerden de etkilenebilmektedir (Özsoy \& Yıldız, 2013). Bu nedenle, erken çocukluk döneminde çocuk ve aileyi bir bütün olarak düşünmek gerekir. Her çocuğun kişisel özelliklerinin yanı sıra, farklı bir aile ortamına sahip olması her birinin farklı özellikte bir birey olmasina neden olmaktadir.

Toplulukların birlikte yaşamalarını gerektiren koşulların artması nedeniyle farklı ülkelerin, kültürlerin tanınması ve bilinmesinin önemi giderek artmaktadır. Bu nedenle çocuklara, okul öncesi eğitimi basamağından itibaren diğer ülkelerin çeşitli özelliklerinin ve kültürlerinin konu alındığı eğitim programlarının hazırlanmasının önemli olduğu görülmektedir (Polat, 2007). Farklı özellikteki bireylerle bir sınıfı paylaşarak müfredatta ve öğretimde yapılan uygulamalar ile tutumlarda olumlu bir değişiklik olmaktadır (Brinson, 2001).Bu nedenle tüm bilgi, beceri, tutumlar vb. kazandırılırken aileleri de eğitimin bir parçası olarak görmek gerekir. Ancak bazen tüm aileleri sınıfta aktif katılımcılar olmaya teşvik etmek zor olabilir. Kendilerini daha etkili olarak algılayan ailelerin, okul öncesi dönemde çocuklarının eğitimine daha fazla dahil oldukları görülmektedir (Pelletier \& Brent, 2002).

Erken çocukluk dönemi, çeşitlilik hakkında pozitif bir farkındalık yaratmak için kritik bir süreçtir (Murray, 2012). Okul öncesi dönem çocukları insanlar arasındaki farklılıkları ayırt etmekte daha iyi olduğundan farkl1lıklara sayg1 eğitimi açısından erken çocukluk öğretmenleri (okul öncesi öğretmenleri) ve eğitim programları birincil kaynak olarak görülmektedir. Onlar insanların fiziksel karakterlerine göre eşleme, adlandırma ve tanımlama yaparlar (Aboud, 1988). Çocuklar farklı kültürler ve farklı kimliklerle karşılaştıklarında eğitimci en önemli rolü üstlenir. Öğretmen ve öğrenciler birbirinin geçmişlerine saygı duyarak onların ailelerini ve kültürlerini onurlandırırlar (Souto-Manning \& Mitchell, 2009).

Farklılıklara saygı eğitimi kapsamında nasıl bir eğitim sürecinin planlanması gerektiği, hangi yöntemlerin bu aşamalarda işe koşulması gerektiği ve de bu sürecin hangi paydaşların katılımıyla gerçekleştirileceği amaca ulaşmak açısından önemlidir. Farklılıklara saygı eğitim programının etkili bir şekilde yürütülebilmesi için, ailelerle yapılacak işbirliği bu hususta büyük önem taşımaktadır. Eğitimciler yeni ve tartışma yaratabilecek eğitim yöntemlerini kullanacaklarsa, aileleri eğitimin bir parçası yapmadıkları sürece başarısız olmaları muhtemeldir (Ross, 1995, aktaran Ekmişoğlu, 2007). Dolayısıyla planlanan eğitici etkinliklere iş birliği içinde ailenin katılımı sağlanmalı, zenginleştirilen etkinlikler farklı aile yapılarını, sosyal ve kültürel çevrelerin özelliklerini de taşımalıdır (Vandenbroeck, 2000). Çocuklarının okuldaki ve evdeki öğrenme faaliyetlerine anne babaların katılımları da bunu yapmanın en iyi yollarından biridir (Aktaş Arnas, 2013). Çünkü aile katılımı paylaşma, bilgi ve ilişki kurmanın bir parçasıdır; görünmeyen programın temel kurumu olduğu kadar çocukların dünyaları arasında da bir tutarlılık köprüsü oluşturur. Çocukta başarıyı arttıran dürüstlük, karşı1lıkı saygı ve ailelerle kurulan olumlu ilişkilerdir (Oktay, Gürkan, Zembat \& Polat Unutkan, 2006). Aile katılımının en büyük getirilerinden birisi de, çocuklarda görülen akademik 
başarının artışı yönündedir. Okul başarısında ailenin etkisi ile ilgili bir araştırmada; aileleri tarafından eğitim konusunda desteklenen çocukların ilkokul başlangıcında okulda daha başarılı olduklarını belirleyerek okul-aile işbirliğinin okul başarısının ön koşulu olduğu sonucuna ulaşmıştır (Özel, Konca \& Çağdaş, 2016). Bu nedenle özellikle son senelerde aile katılımı ulusal okul öncesi eğitim programlarının temel unsurları arasında yer almaktadır. Okul öncesi eğitim programında aile katılımı yoksa o program eksik olarak ifade edilmektedir (Fantuzzo, ButloskyShearer, McDermott, McWayne, Frye \& Perlman, 2007). Özbek (2011)'in yaptığ bir araştırmada, 60-72 aylık çocuklara uygulanan aile katılımlı ilköğretime hazırlık programının çocukların ilköğretime hazır bulunuşluk düzeyine etkisini incelemiştir. Araştırma sonucuna göre Aile Katılımlı İlköğretime Hazırlık Programının çocukların ilköğretime hazır oluşlarını olumlu yönde etkilediği görülmüştür.

Farklılıklara saygı eğitimi programında aile katılımının hedeflerini Derman Sparks (1989, aktaran Topçubaş1, 2015) şu şekilde sıralamıştır:

- Eğitimcilerin aile ile karşılıklı eğitim sürecini kolaylaştırmak ve işbirliği halinde sorunlara birlikte çözüm üretmelerini desteklemek,

- Eğitim programının planlanmasına, uygulanmasına ve değerlendirmesine ailelerin de dahil edilmesini sağlamak,

- Ailelerin, çocuklarda sınıfsal, etnik ve toplumsal cinsiyet kimliklerini nasıl oluşturduklarını ve cinsiyete dayalı ayrımcılığın, ırkçılığın ve engelliliğe dayalı ayrımcılığın çocuğun gelişimini nasıl etkilediğini anlamalarını sağlamak,

- Ailelerin birbirleriyle tartışabilecekleri güvenli bir ortamda farklılıklara saygı eğitimindeki çalışmalar neticesinde ortaya çıkan konuların görüşülmesini sağlamak

Üner (2011), okul öncesi eğitim programındaki 36-72 aylık çocuklara farklılıklara sayg1 eğitimi kazandırmanın öğretmen görüşleri doğrultusunda değerlendirilmesi adlı araştırmasında 'Farklılıklara Saygı Eğitimi'" programına katılan çocukların, bu konuda geliştirdikleri olumlu ve olumsuz davranışları öğretmen görüşlerine göre değerlendirmiştir. Araştırmasının sonucunda okul öncesi öğretmenlerinin düşüncelerine göre uygulanan farklılıklara saygı eğitiminin çocuğun tüm gelişim alanlarına katkı sağladığı, çocukların önyargılarından uzaklaşmasına, kendini tanımasına, empati kurabilmesine kendilerinden fiziksel ve kişisel olarak farklı kimliklere karşı olumlu bir tavır geliştirmelerine yardımcı olduğu tespit edilmiştir. Eren (2015) ise, öyküleştirme yöntemine dayalı eğitimin beş yaş çocuklarında farklılıklara saygı kazanımına etkisinin incelenmesi adlı araştırmasında beş yaş grubu çocuklarına farklı1ıklara saygı kazanımına yönelik öyküleştirme yöntemine dayalı bir eğitim program örneği hazırlamıştır. Araştırmanın sonuçları, öyküleştirme yöntemine dayalı eğitimin farklılıklara saygı kazanımlarına olumlu etkisinin olduğunu göstermiştir.

Dünyada yaşanan savaşlar, orada yaşayan insanların ülkemizin de arasında olduğu başka ülkelere göçü zorunlu kılmıştır. Göçle birlikte farklı kültürlerin karşılaşması söz konusu olmakta ve bu sayede insanların bir arada hayatlarını sürdürme isteği uyum sağlama süreciyle bir arada gerçekleşmektedir. Ancak kimi zaman bu süreç uyumsuzluk ve çatışma boyutuna varabilmekte, kültürler arasında iletişim kopuklukları ortaya çıkabilmektedir (Akıncı, Nergiz \& Gedik, 2015). Bu da birbirinden farklı toplum ve kültürlerin bir arada yaşamasından doğabilecek karmaşayı en aza indirebilmek için küçük yaştan itibaren çocuklara uygulanacak paket programlara duyulan ihtiyac1 arttırmıştır. Erken yaşta bu eğitime başlamanın önemi, ailenin de bu eğitime katılımı, farklılıkları kabul ederek birlikte yaşama becerisine sahip bireylerin yetişebilmesi açısından önemlidir.

Farkl11ıklara saygı eğitiminin okul öncesi eğitim programında yer alan tüm etkinlik türleriyle verilmesinin, farklı öğrenme stillerine sahip olan çocukların bu konuda olumlu bakış açıları geliştirmeleri açısından önemli olduğu düşünülmektedir. Farklılıklara saygı kazanımında okul öncesi dönemin önemi ve özellikle bu dönemde eğitimin kalıcılığı ve sürekliliği için aile katılımının da sağlanması gerektiğinden, çalışmanın problemini " 5-6 Yaş Grubu için Geliştirilen Aile Katılımlı Farklılıklara Saygı Programının Çocukların Farklılıklara Saygı Düzeyine Etkisi nedir?” ifadesi oluşturmaktadır.

$\mathrm{Bu}$ araştırmanın temel amacı " 5-6 yaş grubu için geliştirilen Aile Katılımlı Farklılıklara Saygı Programının çocukların farklı1ıklara saygı düzeyine etkisi”ni incelemektir. $\mathrm{Bu}$ amaç doğrultusunda aşağıdaki sorulara yanıt aranmıştır; 
1. "5-6 Yaş Grubu İçin Geliştirilen Aile Katılımlı Farklılıklara Saygı Programı” uygulamaları öncesi yapılan değerlendirme sonuçlarına göre deney ve kontrol grubu çocuklarının "Farklılıklara Saygı Ölçeği”nden elde edilen ön test puanlarının ortalamaları arasında anlamlı farklılık var mıdır?

2. “5-6 Yaş Grubu İçin Geliştirilen Aile Katılımlı Farklılıklara Saygı Programı” uygulamaları sonrası yapılan değerlendirme sonuçlarına göre deney ve kontrol grubu çocuklarının "Farklılıklara Saygı Ölçeği”nden elde edilen son test puanlarının ortalamaları arasında anlamlı farklılık var mıdır?

3. "5-6 Yaş Grubu İçin Geliştirilen Aile Katılımlı Farklılıklara Saygı Programı” uygulama öncesi ve sonrası yapılan değerlendirme sonuçlarına göre deney grubu çocuklarının "Farklılıklara Saygı Ölçeği"nden elde edilen ön test-son test puan ortalamaları arasında anlamlı farklılık var mıdır?

4. "5-6 Yaş Grubu İçin Geliştirilen Aile Katılımlı Farklılıklara Saygı Programı” uygulama öncesi ve sonrası yapılan değerlendirme sonuçlarına göre kontrol grubu çocuklarının "Farklılıklara Saygı Ölçeği"nden elde edilen ön test-son test puan ortalamaları arasında anlamlı farklılık var mıdır?

Milli Eğitim Bakanlığı tarafından hazırlanan ve uygulamaya sunulan 2013 yılı okul öncesi programında sosyal ve duygusal gelişimle ilgili kazanımlar arasında farklılıklara saygı kazanımına da yer verildiği görülmektedir (MEB, 2013). Ancak alanda yapılan uygulamaların ve bu konu ile ilgili geliştirilen programların ve uygulamalar ile ilgili çalışmaların (KEDV, 2004; Eren, 2015, Erdoğan \& Baş, 2018) da oldukça sınırlı olduğu görülmektedir. Saygı değerinin temelini oluşturan farklılıklara saygı gibi önemli bir kazanımın tüm eğitim sürecine yayılması önemlidir. Bu nedenle öğrenmelerin en hızlı olduğu erken çocukluk döneminde, aile katılımının da temel alınarak, kazanım ve göstergeler doğrultusunda hazırlanan farklılıklara saygı programlarının daha sık uygulanması önemlidir.

Okul öncesi dönemde öğrenme en etkili şekilde "nasıl gerçekleşebilir?", sorusuna yıllardır aranan yanıtlar aile katılımlı programların daha etkili olduğunu göstermiştir. Yahya (2016)'ya göre eğitimcilerin ailelerle iletişim halinde olması, ev ziyaretleri yapmaları ailelerin kültürel mirasına katkı sağladığı gibi oyuna dayalı öğrenmeye dair çocuklarına da olumlu katkıda bulunacaktır.

$\mathrm{Bu}$ nedenle çocuktaki bilinç ve farkındalık gelişimini hızlandırabilmek ve farklılıklara saygı konusunda kalıcı öğrenmeleri oluşturabilmek açısından aile katılımlı farklılara saygı programının hazırlanması ve uygulanmasının çocuklar açısından ön yargıların olmadığı ötekileştirmenin olmadığı bir bakış açısının kazanılması açısından daha etkili olduğu düşünülmektedir. Okul öncesi eğitim alanında çalışan eğitimcilerin ve araştırmacıların farklılıklara saygı konusuna dikkatleri çekmek ve yol gösterici çalışmalara adım atmaları açısından da önemlidir.

$\mathrm{Bu}$ nedenle "5-6 Yaş Grubu İçin Geliştirilen Aile Katılımlı Farklılıklara Saygı Programı" nın uygulama örnekleri sunması açısından alana katkı sağlayacağı düşünülmektedir. Ayrıca yapılan bu çalışmanın bir program sınamas1 olması bakımından alana özgün sonuçlar sunacağ1 tahmin edilmektedir. Araştırma okul öncesi dönemde gerçekleştirilen bir programa aile katılımının ne boyutta ve nasıl gerçekleştirilebileceğine dair birincil elden somut veriler sunabilecektir.

\section{Araştırma Modeli}

\section{Yöntem}

Araştırmada "5-6 Yaş Grubu İçin Geliştirilen Aile Katılımlı Farklılıklara Saygı Programı”nın çocukların farklılıklara sayg1 düzeyine etkisini incelemek amacıyla nicel araştırma yöntemlerinden olan deneysel desen kullanılmıştır. Deneysel desenin temel amac1, sonuç üzerinde etkisi olabilecek tüm dışsal faktörleri kontrol ederek, bir deneysel işlemin veya müdahalenin sonuç üzerindeki etkisinin test edilmesidir (Creswell, 2013). Çalışma deneysel modellerden eğitim ve sosyal bilimlerde sıklıkla kullanılan Ön Test- Son Test Kontrol Gruplu Desene uygun olarak tasarlanmıştır. Buna göre önceden hazırlanmış gruplara deney ve kontrol grubu ataması yapılmaz. Her iki grup da random (seçkisiz) atamalarla oluşturulur (Büyüköztürk, 2007).

Çalışmada, deney grubuna "5-6 Yaş Grubu İçin Geliştirilen Aile Katılımlı Farklılıklara Saygı Programı" uygulanırken, kontrol grubuna bu eğitim programı uygulanmamıştır. Programın öncesinde ve sonrasında iki gruba da son test olarak "Farklılıklara Saygı Ölçeği” uygulanmıştır. 
Çocukların farklılıklara saygı düzeyine etkisi incelenen bu çalışmanın bağımsız değişkeni "5-6 Yaş Grubu İcin Geliştirilen Aile Katılımlı Farklılıklara Saygı Programı” dır. Çalışmanın bağımlı değişkeni ise çocukların farklılıklara saygı düzeyidir. Bu bağlamda bağımsız değişkenin, bağımlı değişkenler üzerindeki etkisi incelenmiştir.

\section{Çalışma Grubu}

Araştırmada "5-6 Yaş Grubu İçin Geliştirilen Aile Katılımlı Farklılıklara Saygı Programı"nın çocukların farklılıklara sayg1 düzeylerini incelemek üzere deney-kontrol gruplanı oluşturulmuştur. Araştırmanın çalışma grubu 2015-2016 eğitim ve öğretim yılı bahar döneminde İstanbul ilinin Kadıköy ilçesinde yer alan Marmara Üniversitesi Atatürk Eğitim Fakültesi Prof. Dr. Ayla Oktay Okul Öncesi Eğitim Uygulama Birimi'ne devam eden 23 çocuktan oluşmaktadır. Deney-kontrol grupları oluşturulurken kız- erkek çocuklarının sayılarına dikkat edilerek rastgele yöntemle kura çekilerek 12 kişilik deney grubu ( 7 kı 5 erkek), 11 kişilik kontrol grubu (7 kız 4 erkek) oluşturulmuştur.

Deney ve kontrol grubundaki çocuklar üç yaşında Marmara Üniversitesi Atatürk Eğitim Fakültesi Prof. Dr. Ayla Oktay Okul Öncesi Eğitim Uygulama Birimi’ne başlamış olup ilerleyen yıllar boyunca aynı eğitim ortamında bulunmuş ve aynı programa katılmışlardır. Bu nedenle çocukların eğitim ortamından kaynaklı öğrenmeleri de benzeşiktir.

\section{Veri Toplama Aracı}

$\mathrm{Bu}$ araştırmanın temel veri toplama arac1, 4-6 yaş grubuna yönelik olarak Ekmişoğlu (2007) tarafından geliştirilen "Farklılıklara Saygı Ölçeği” dir. Ölçek cinsiyet, aile sosyal yaşam, engel durumu ve farklı kültürel geçmiş durumu olmak üzere dört alt boyuttan oluşmaktadır. İç tutarlılık kat sayısı ,69 (Ekmişoğlu, 2007) olup, Kalayc1 (2005)'ya göre oldukça güvenilirdir.

Aile Katılımlı Farklılıklara Saygı Programı'nın etkisini tespit etmek amaciyla program öncesinde ve sonrasında “Faklılılara Saygı Ölçeği” uygulanmıştır.

\section{5-6 Yaş Grubu İçin Geliştirilen Aile Katılımlı Farklılıklara Saygı Programı}

5-6 Yaş Grubu İçin Geliştirilen Aile Katılımlı Farklılıklara Saygı Programı'nın hazırlanması sırasında ilk önce programın kapsam geçerliliği test edilmiştir. Alanda uzman 7 kişiye gönderilen "5-6 Yaş Grubu İçin Geliştirilen Aile Katılımlı Farklılıklara Saygı Programı" etkinlikleri p=.05 anlamlılık düzeyine göre kapsam geçerlilik oranının değeri .99 olarak, kapsam geçerlilik indeksinin değeri de, 1 olarak elde edilmiştir.

\section{5-6 Yaş Grubu İçin Geliştirilen Aile Katılımı ıarklııklara Saygı Programı’nın İçeriği ve Uygulanması}

Araştırmada çocukların farklılıklara saygı düzeyini arttırmak için araştırmacı tarafından "5-6 Yaş Grubu İçin Geliştirilen Aile Katılımlı Farklılıklara Saygı Programı" hazırlanmıştır. "5-6 Yaş Grubu İçin Geliştirilen Aile Katılımlı Farklı1ıklara Saygı Programı” deney grubuna 2015-2016 eğitim öğretim yılının Şubat ayından başlayıp Mayıs ayının sonuna kadar 14 hafta süresince araştırmacı tarafından bizzat uygulanmışıır.

Yapılandırmacı yaklaşım temel alınarak hazırlanan "5-6 Yaş Grubu İçin Geliştirilen Aile Katılımlı Farkl11ıklara Saygı Programı" haftada 3 gün her güne birer tane olmak üzere toplam 52 tane bütünleştirilmiş etkinlikten oluşmaktadır. Her bütünleştirilmiş etkinlik ise, kendi içinde aşamalı üçer etkinliği içermektedir.

Bütünleştirilmiş Etkinlikler MEB (2013) Okul Öncesi Eğitim Programındaki kazanım göstergelere ve etkinlik planı formatına uygun olarak yazılmış; aktif pasif sıralamasına dikkat edilmiş; mümkün olduğu kadar tüm gelişim alanlarından kazanım ve göstergelerin alınmasına özen gösterilmiş ve Türkçe, Sanat, Drama, Müzik, Hareket, Oyun, Fen, Matematik, Okuma Yazmaya Hazırlık ve Alan Gezileri geliştirilmiştir. Tüm program boyunca uygulanan etkinliklerde kullanılan materyallerin öğretmenlerin kolay temin edebilecekleri materyaller olmasına ve etkinliklerin mevcut programın içerisine kolayca adapte edilebilmesi temel olarak alınmıştır.

Her etkinlik için çocukların aktif katılımıyla yapılacak betimsel, kazanımlara yönelik, duyuşsal ve yaşantısal sorular hazırlanmış ya da farklı değerlendirme etkinlikleri oluşturulmuştur. Programın devamlılığını sağlamak ve öğrenmeleri pekiştirmek amacıyla, 14 hafta süresince okulda uygulanan etkinliklere paralel olarak araştırmacı tarafından hazırlanan çalışma sayfaları ailelere gönderilmiştir.

\section{Verilerin Toplanması}

Araştırmada, deney ve kontrol grubundaki çocukların farklılıklara sayg1 düzeylerini değerlendirmek amaciyla "Farklılıklara Saygı Ölçeği” ön test olarak uygulanmıştır. Ardından deney grubuna "5-6 Yaş Grubu İçin Geliştirilen Aile Katılımlı Farklılıklara Saygı Programı"nın uygulama sürecine geçilmiştir. Programın 1. haftasında aile katılımı olmadan araştırmacı tarafından programa giriş yapılmış, ardından 12 hafta süresince aileler çocuklarılla birlikte 
hazırladıkları hikaye sunumlarını yaparak haftalık aile katılımı etkinliğini yapmışlardır. Daha sonra günlük eğitim akışına devam edilerek "5-6 Yaş Grubu İçin Geliştirilen Aile Katılımlı Farklılıklara Saygı Programı"ndaki o güne ait geliştirilmiş olan bütünleştirilmiş etkinlik uygulanmıştır. 14. Hafta da aile katılımı olmadan araştırmacı genel değerlendirme etkinlikleri yaparak programın uygulaması tamamlanmıştır.

Kontrol grubunda bulunan çocuklara ise kendi sınıflarında, sınıf öğretmenleri tarafından MEB (2013) Okul Öncesi Eğitim Programı temel alınarak hazırlanmış olan rutin program uygulanmaya devam etmiştir. "5-6 Yaş Grubu İçin Geliştirilen Aile Katılımlı Farklılıklara Saygı Programı” bu gruba uygulanmamıştır.

14 hafta süren "5-6 Yaş Grubu İçin Geliştirilen Aile Katılımlı Farklılıklara Saygı Programı'nın” ardından bir hafta boyunca deney ve kontrol gruplarına "Farklılıklara Saygı Ölçeği” son test olarak tekrar uygulanmıştır.

\section{Verilerin Çözümlenmesi}

Veriler SPSS 16.0 İstatistiksel Paket Programı kullanılarak analiz edilmiştir. Araştırmada elde edilen veriler, her bir okul için deney ve kontrol gruplarının $(\mathrm{N}<30)$ öğrenciden oluşmakta olup, çalışma grubundaki deney ve kontrol gruplarının üye sayısı 30'dan az ise parametrik olmayan testler kullanılması gerektiğinden (Ross, 2004'den akt. Delice, 2010) non parametrik istatistiksel yöntemlerle analiz edilmiştir. Deney ve kontrol grupların ön test sonuçları arasında fark olup olmadığını belirlemek amacı ile Mann Whitney-U testi yapılmıştır. Deney grubunun ön test ve son test toplam puanları karşılaştırmak için Wilcoxon İşaretli Sıralar Testi kullanılmıştır. Deney ve kontrol grubunun son test puanları arasında fark olup olmadığı Mann Whitney-U testi ile kontrol edilmiştir.

\section{Bulgular ve Yorum}

Bu bölümde, MEB (2013) Okul Öncesi Eğitim Programı'nın yanı sıra "5-6 Yaş Grubu İçin Geliştirilen Aile Katılımlı Farklılıklara Saygı Programı'nın uygulandığı deney grubu ile yalnız MEB (2013) Okul Öncesi Eğitim Programı'nın uygulandığı kontrol grubunun farklılıklara saygı düzeyine ilişkin veriler tablolar şeklinde aşağıda sunulmuştur.

Tablo 1. Farklılıklara Saygı Ölçeği Ön Test Puanlarının Deney ve Kontrol Grupları Değişkenine Göre Farklılaşıp Farklılaşmadığını Belirlemek Üzere Yapılan Mann Whitney-U Testi Sonuçları

\begin{tabular}{llllllll}
\hline & Gruplar & $N$ & $\bar{x}_{\text {sira }}$ & $\sum_{\text {sira }}$ & U & z & p \\
\hline Farkliliklara Sayg1 & Deney & 12 & 13.50 & 162.00 & \multirow{2}{*}{48.000} & -1.112 & \multirow{2}{*}{.266} \\
\cline { 2 - 2 } & Kontrol & 11 & 10.36 & 114.00 & & \\
\hline
\end{tabular}

Tablo 1'den de anlaşılacağı üzere, çalışmaya katılan çocukların Farklılıklara Saygı Ölçeği'nden almış oldukları ön test puanlarının deney ve kontrol grupları değişkenine göre anlamlı bir şekilde farklılaşıp farklılaşmadığını belirlemek üzere yapılan Mann Whitney-U testi sonucunda gruplar arasında anlamlı bir farklılık görülmediği bulunmuştur ( $\mathrm{z}=-1.112 ; \mathrm{p}>.05)$. Deney ve kontrol grubunun farklılıklara saygı düzeyleri bakımından ön test puanları incelendiğinde iki grubun uygulama öncesinde denk olduğunu söylemek mümkündür.

Tablo 2. Farklılıklara Saygı Ölçeği Son Test Puanlarının Deney ve Kontrol Grupları Değişkenine Göre Farklılaşıp Farklılaşmadığını Belirlemek Üzere Yapılan Mann Whitney-U Testi Sonuçları

\begin{tabular}{lllccccc}
\hline & Gruplar & $N$ & $\bar{x}_{\text {sira }}$ & $\sum_{\text {sira }}$ & U & z & p \\
\hline Farkl1l1klara Sayg1 & Deney & 12 & 14.83 & 178.00 & 32.000 & -2.104 & .036 \\
Son test & Kontrol & 11 & 8.91 & 98.00 & \\
\hline
\end{tabular}

Tablo 2'den de anlaşılacağı üzere, çalışmaya katılan çocukların Farkl11ıklara Sayg1 Ölçeği'nden almış oldukları son test puanlarının deney ve kontrol grupları değişkenine göre anlamlı bir şekilde farklılaşıp farklılaşmadığını belirlemek üzere yapılan Mann Whitney-U testi sonucunda grupların sıra ortalamaları arasındaki farklılık anlamlı bulunmuştur $(\mathrm{z}=-2.104 ; \mathrm{p}<.05)$. Söz konusu farklılık deney grubu lehine gerçekleşmiştir. 
Tablo 3. Deney Grubu Ön Test- Son Test Puanları Arasındaki Farkın Anlamlılı̆̆ı İçin Yapılan Wilcoxon Analizi Sonuçları

\begin{tabular}{lccccc}
\hline Son test- Ön test & $N$ & $\bar{x}_{\text {sira }}$ & $\sum_{\text {sira }}$ & $\mathbf{z}$ & $\mathbf{p}$ \\
\hline Negatif Sira & 1 & 2.50 & 2.50 & & \\
Pozitif Sira & 9 & 5.83 & 52.50 & -2.563 & .012 \\
Eşit & 2 & - & - & & \\
\hline
\end{tabular}

Tablo 3'de görüldüğü gibi, deney grubu çocuklarının Farklılıklara Saygı Ölçeği’nden aldıkları ön test ve son test puanları arasında anlamlı bir farklılık bulunup bulunmadığını belirlemek amacıyla yapılan Wilcoxon testi sonucunda deney grubu çocuklarının ön test puanları ile son test puanları arasındaki farklılık istatistiksel olarak anlamlı bulunmuştur $(\mathrm{z}=-2.563 ; \mathrm{p}<.05)$. Söz konusu farklılık son test lehine gerçekleşmiştir. Yani yapılan çalışma deney grubu çocuklarının farklılıklara saygı düzeylerini anlamlı bir şekilde yükseltmiştir.

Tablo 4. Kontrol Grubu Ön Test- Son Test Puanları Arasındaki Farkın Anlamlılığı İçin Yapılan Wilcoxon Analizi Sonuçları

\begin{tabular}{lccccc}
\hline Son test- Ön test & $N$ & $\bar{x}_{\text {sira }}$ & $\sum_{\text {sira }}$ & z & $\mathbf{p}$ \\
\hline Negatif Sira & 3 & 5.00 & 15.00 & & \\
Pozitif Sıra & 6 & 5.00 & 30.00 & -.892 & 0.373 \\
Eşit & 2 & & & & \\
\hline
\end{tabular}

Tablo 4'te de görüldüğü gibi, kontrol grubu çocuklarının Farklılıklara Saygı Ölçeği ön test son test puan ortalamaları arasında anlamlı bir farklılık bulunup bulunmadığını belirlemek amacıyla yapılan Wilcoxon testi sonucunda kontrol grubunda yer alan çocukların farklılıklara saygı puanları arasındaki farklılık istatistiksel olarak anlamlı bulunmamıştır $(\mathrm{z}=-.892 ; \mathrm{p}>.05)$. Yani kontrol grubuna uygulanan programın farklılıklara saygı düzeyi puanlarını değiştirmediği ortaya çıkmıştır.

\section{Sonuç, Tartışma ve Öneriler}

“5-6 Yaş Grubu İçin Geliştirilen Aile Katılımlı Farklılıklara Saygı Programı”nın etkisini incelemek amacıyla yapılan çalışmada "5-6 Yaş Grubu İçin Geliştirilen Aile Katılımlı Farklılıklara Saygı Programının” çocukların farklılıklara sayg1 düzeyini olumlu yönde etkilediği söylenebilir. İlgili alan yazın incelendiğinde çocukların farklılıklara saygıyı nasıl geliştirdiklerini araştıran çalışmalara az rastlanmaktadır (Palmer, 1990; Black-Gutman \& Hickson, 1996; Doyle \& Aboud, 1995). Ülkemizde farklılıklara saygı kapsamında değerlendirilebilecek program örnekleri mevcut olsa da (KEDV, 2004; Eren 2015, Erdoğan \& Baş 2018) "5-6 Yaş Grubu İçin Geliştirilen Aile Katılımlı Farklılıklara Saygı Programı"nın aile temelli olması açısından önemlidir.

"5-6 Yaş Grubu İçin Geliştirilen Aile Katılımlı Farklılıklara Saygı Programı”nın etkisini incelemeyi amaçlayan araştırmanın bulguları doğrultusunda "5-6 Yaş Grubu İçin Geliştirilen Aile Katılımlı Farklılıklara Saygı Programı" uygulamaları öncesi yapılan değerlendirme sonuçlarına göre deney ve kontrol grubu çocuklarının farklılıklara saygı ön test puanları arasındaki anlamlı farklılığı belirlemeye yönelik yapılan analiz bulgularına göre; farklı1ıklara saygı ölçeği puanları arasında anlamlı bir farklılık bulunmamıştır. Bu sonuç doğrultusunda oluşturulan deney ve kontrol grubunda yer alan çocukların farklılıklara saygı puanlarının uygulama öncesi birbirine yakın olduğu söylenebilir. Uygulanan "5-6 Yaş Grubu İçin Geliştirilen Aile Katılımlı Farklılıklara Saygı Programının” etkililiğinin tespit edilebilmesi için bu grupların birbirine yakın olması önemlidir. Buradan hareketle bu sonuç; yapılan çalışma sonucunda elde edilen bulguların geçerli olduğunu ortaya koyması açısından önemlidir. Deney ve kontrol grubunda yer alan çocukların sıra ortalama puanlarına bakıldığında deney grubunda yer alan çocukların puan ortalamaları kontrol grubunda yer alan çocukların puan ortalamalarına göre daha yüksektir. Bu sonuç uygulanan 5-6 Yaş Grubu İçin Geliştirilen Aile Katılımlı Farklılıklara Saygı Programı'nın etkili olduğunu ortaya konmuştur. İlgili literatür incelendiğinde, araştırmamızı destekleyen uluslararası programlara rastlamak mümkündür. Farklılıklara saygı ve bir diğer ifadeyle ön yargı karşıtı eğitim programları incelendiğinde farklılıklara saygı eğitimi programının temellerini 1980’li yılların başında Ramsey (1987)'in, “Çok Kültürlü Eğitim Yaklaşımını” geliştirdiği “Teaching and Learning in a Diverse World - Multiculturel Education for Young Children" isimli kitabında ortaya atıldığı görülmektedir. Çok 
kültürlü eğitimin kültürel farklılıkların etkisi ile ortaya çıktığını ve birçok boyut ile çevrelendiğini ortaya koymuştur. Bir diğer araştırmacı Derman Sparks (1989), ilk defa Amerika'da önyargı ve ayrımcılık temalarını temeline alan AntiBias Curriculum (Önyargı Karşıtı Müfredat) geliştirmiş ve bu çalışma kitap haline getirilmiştir. Derman Sparks yayınlanan bu çalışmasında önyargı programının önemini, önyargı programı uygulanan bir sınıftaki çevre düzenlemesini, ırksal farklılık ve benzerlikleri belirtmiştir. Ayrıca geliştirilen bu önyargı programında engelli olma durumu, cinsel kimlik, kültürel farklılık ve benzerlikler, ayrımcılık davranışlarına karşı mücadele, çocuklarla ve ailelerle aktif bir şekilde çalışma ve kendi kendine eğitim başlıkları açıklanmıştır. Program, çocukların ayrımcılık fikirlerinden uzaklaştırılarak olumlu öz kavramlar geliştirmelerini sağlamıştır. Rosenzweig (1998) ise, doktora tezinde okul öncesi dönemde sosyal biliş gelişimi üzerine çok kültürlü programın etkisini incelemiştir. Rosenzweig, sosyal biliş teorisinde çocuklar kendi ve diğer insanların kimliklerini, sosyal ve ahlaki ilişkileri nasıl yapılandırdıkları ortaya koymuştur.

$\mathrm{Bu}$ çalışmadaki bulguları destekler nitelikte olan ve ülkemizde yapılan benzer çalışmalar incelendiğinde KEDV, (2004) tarafından "Erken Çocuklukta Kültürel Çeşitliliğe Saygı" çalışmasının, bu alanda yapılan ilk proje olduğu görülmüştür. Avrupa Birliği desteğiyle KEDV tarafından Aralık 2004 - Mart 2006 tarihleri arasında uygulanan bu proje kapsamında çocuklar ve yetişkinler için eğitim programları geliştirilmiştir. "Erken Çocuklukta Farklılıklara Saygı Eğitimi El Kitabı" ismiyle yayınlanan bu kaynakta, programın tamamı açık ve anlaşılır bir şekilde ifade edilmiştir. Diğer bir çalışma ise Ekmişoğlu (2007) tarafından, okul öncesi öğretmenlerinin farklılıklara saygı kavramı hakkında görüşlerini inceleyen araştırmadır. Belirlenen bu görüşlere dayalı olarak "Farklılıklara Saygı Ölçeğì" geliştirmiştir. Araştırmanın sonucunda, çocukların farklılıklar kavramıyla ilgili bilgi ve yaşantılarının yeterli olmadığı görülmüştür. Bu durum ise farklılıklara saygı kazanımının, okul öncesi eğitim programımıza yeni dâhil edilmesi (MEB, 2006) ve eğitimcilerin bu konuda gereken yeterliliğe sahip olmaması ile açıklamıştır. Bu araştırmalara ek olarak Eren (2015) yaptığı çalışmada, beş yaş grubu çocuklarla öyküleştirme (Storyline) yöntemine dayalı eğitim alan ve almayan çocukların farklılıklara saygı kazanımları arasında farklılık olup olmadığını incelemiştir. Bu çalışmanın sonuçlarına göre MEB (2013) Okul Öncesi Eğitim Programına ait günlük rutin etkinliklerin yanı sıra, öyküleştirme yöntemine dayalı bir eğitimle çocuklara farklılıklara saygının kazandırıldığı söylenmiştir. Son olarak başka bir çalışma Erdoğan ve Baş (2018), çocuk edebiyatı ürünlerinden faydalanarak 4-6 yaş çocuklarına yaratıcı drama yöntemiyle özel gereksinimli birey farkındalığının kazandırılmasını amaçlamıştır. Araştırmanın sonucunda, çocukların tamamı farklılık ve engel durumunu fark etme, yetersizlik alanlarında bilgi ve farkındalık kazanma, olumlu tutum geliştirmede puan artışı sağlamıştır. Tüm bu araştırmaların sonuçları çalışmanın bulguları destekler niteliktedir.

“5-6 Yaş Grubu İçin Geliştirilen Aile Katılımlı Farklılıklara Saygı Programı”nın etkisini incelemek amacıyla yapılan araştırmada elde edilen bulgular doğrultusunda 5-6 Yaş Grubu İçin Geliştirilen Aile Katılımlı Farklılıklara Saygı Programı uygulamaları sonrası yapılan değerlendirme sonuçlarına göre deney ve kontrol grubu farklılıklara sayg1 son test puanları arasında anlamlı bir farklılık bulunmuştur. Buna göre deney grubunda yer alan çocuklara uygulanan Aile Katılımlı Farklı1ıklara Saygı Programı çocukların farklılıklara saygı düzeylerini olumlu yönde etkilemiştir. Uygulanan bu program 5-6 yaş grubu çocuklarda farklılıklara düzeyinin gelişmesinde olumlu katk1 sağladığı saptanmıştır. Başka bir deyişle, ön yargıların oluşmaması ve farklı olana saygı duymanın erken yaşta geliştirilmesinde "Aile Katılımlı Farklılıklara Saygı Programı" etkilidir.

Connolly, Smith, Kelly (2009) Kuzey İrlanda'daki Katolik ve protestan çocukların etno dini gelenekleri arasındaki var olan etnik farklılıkları hakkında üç yaşından itibaren anlayış geliştirerek diğerine karşı olumsuz davranışlar gösterdiğini söylemektedir. Başka bir araştırma da Aboud ve arkadaşları ise farklı özellikteki bireylerden oluşmuş grup çalışmalarının insanların farklılıklara saygı duymalarını güçlendirdiğini vurgulamıştır (York, 2016). Anne babaların öğrenme kuramlarının temel ilkelerini ve okuldaki pedagojik uygulamalarla ilgili kaygılarını belirlemek için göçmen annelerin erken öğrenme konusundaki deneyimlerini ve perspektiflerini araştıran bir çalışmada, eğitimcilerin ailelerle diyaloga girmesini; böylece ebeveynlerin kültürel sermayesi ve oyuna dayalı öğrenmeye dair anlayışı geliştirerek çocuklarına katkıda bulunacakları sonucuna varmıştır (Yahya, 2016). Bir diğer araştırma da çocukların eğitimsel deneyimlerine ailelerin katılımı, yıllardır erken çocukluk eğitiminin hayati bir parçası olarak kabul edilmiştir ve ulusal eğitim politikası belirleyicileri, bunu öncelikli olarak kabul etmeye devam 
etmektedir (McWayne, Campos \& Owsianik, 2008). Bu nedenle, erken dönemde çocukların farklılıklara saygı duymalarını geliştirmek için ailelerin de sürecin içerisinde yer alması programın etkililiği açısından son derece önemlidir.

5-6 Yaş Çocuklarına Uygulanan Aile Katılımlı Farklılıklara Saygı Programı, çocuklarda farklılıklara saygının gelişmesini olumlu yönde etkilemiştir. Deney grubunda yer alan çocukların farklılıklara saygı puanları ortalamalarından anlamlı bir farklılık görülmüştür. Kontrol grubunda yer alan çocukların farklılıklara saygı puanları ortalamaları anlamlı bir farklılık ortaya çıkarmamıştır. Farklılıklar ile yaşamları boyunca karşılaşacak olan çocuklar, insanların farklılıklarına saygı duymayı etkili bir erken çocukluk programı ile sağlanabileceğini Vanderbroeck (2000) yaptığı çalışmada belirtmiştir. Bununla birlikte May (1999) da, programda çocukların önyargı ve ayrımcılığa dair farkındalık yaratacak şekilde odaklanması çocukların farklılıklara saygı duymalarını destekleyecek ve sosyal adalete bütünleştirmeye karşı değer yargılarını geliştireceğini belirtmiştir.

Aile Katılımlı Farklı1ıklara Saygı Programı'na katılan çocukların farklılıklara saygı düzeyinin mevcut MEB (2013) programının uygulandığı çocuklardan daha yüksek olması, programın etkililiğinin ispat edildiğini göstermektedir. $\mathrm{Bu}$ sonuç doğrultusunda ilerleyen yıllarda bireyler arasında ortaya çıkacak olan ayırımın ortadan kaldırılması için okul öncesi eğitimde bu programın örnek oluşturması açısından önemli olduğu söylenebilir.

Araştırma sonuçlarına dayanarak, "5-6 Yaş Grubu İçin Geliştirilen Aile Katılımlı Farklılıklara Saygı Programının” çocukların farklılıklara saygı düzeyini olumlu yönde etkilediği söylenebilir.

\section{Öneriler}

Araştırma sonucunda geliştirilen öneriler şu şekilde ifade edilebilir:

- Farklı yaş grupları için de Aile Katılımlı Farklılıklara Saygı Programları geliştirilebilir.

- Farklı değişkenlerin kullanıldığı yeni araştırmalar planlanabilir.

- $\mathrm{Bu}$ araştırma, uzun süreli değerlendirmeler ya da süreklilik içermemektedir. Araştırma kısa sürede olumlu yönde değişiklikler ortaya koymasına rağmen, uzun süreli değerlendirmeler olmaksızın uzun süreli değişiklikler açıklanamayabilir. Bu bağlamda, boylamsal çalışmalar yapılabilir ve kalıcılığına bakılabilir.

- "5-6 Yaş Grubu İçin Geliştirilen Aile Katılımlı Farklılıklara Saygı Programı” Okul Öncesi Eğitim Alanında görev yapan okul müdürlere yöneticilere, rehber öğretmenlere ve öğretmenlere tanıtılarak etkili sınıf içi uygulamaları için destek sağlanabilir.

- Farklılıklara saygıya duyarlı bir sınıf oluşturmak için; farklılıklara saygının eğitim ortamının bir parçası olabilmesine yönelik öğrenme merkezleri oluşturulabilir, varolan öğrenme merkezlerine materyaller eklenerek öğretmenlere model olabilecek örnek eğitim ortamları oluşturulabilir.

- MEB tarafından Farklılıklara saygı kavramının alanda etkili bir şekilde uygulanabilmesine yönelik olarak aile katılımını da içine alan hizmet içi eğitim seminerleri düzenlenebilir.

- MEB, Üniversiteler, Sivil Toplum Kuruluşları, Yayınevleri vb. işbirliği tarafından Farklılıklara saygı kavramını ve uygulamalarını ailelere anlatan "Aile Eğitim Seminerleri” düzenlenebilir.

- Ailelerin farklılıklara saygı konusuyla ilgili bilinçlendirilmesine yönelik film, broşür veya kitaplar hazırlanarak ailelere ulaştırılabilir. 


\section{Extended Summary}

\section{Introduction}

The preschool period is the most intense and fastest period of brain development. Long-term research done in this period show there is a positive relationship between the substantiality and quality of the different environmental stimuli children meet and the development of the child. The child is born in a family and until institutional preschool education begins, grows up and develops here. The family has a great importance on the development and education of the child. In addition to the inherited qualifications for the full use of an individual's capacity, the social, cultural and economic level that the family has, and the environment that is provided to children, have a very important place. Therefore the child and the family should be considered as a whole in early childhood. Besides the children's hereditary traits, having different family environments causes each of them to be individuals with different types of characteristics.

In the socialization period, while the child tries to be himself, staying with people who face away from prejudices, and gaining the perspective of accepting people as they are without othering will provide a considerable contribution to the raising up of a society in peace and tolerance in the future. On the other hand, when the child grows up, this will be supportive of being a peaceful individual who is at peace with himself, and respectful to others. It is important to study the "Respect for Diversity" education in the preschool period when most of the learning takes place. However, it is known that the formation of permanent learning without family support is very difficult in this period. For this reason, while all knowledge, skills, attitudes, and so on are acquired, families also should be seen as a part of the education.

\section{Purpose}

The main aim of this study was to examine the effect of the Respect for Diversity Program with Family Involvement developed for the age group of 5-6 years on the children's level of respect for diversity.

\section{Research Model}

\section{Method}

The study is a quantitative study. A model with a pretest-posttest control group, which is among the experimental models, was used in the study.

\section{Sample}

The study group consisted of a total of 23 children; 12 in the experimental group ( 7 girls, 5 boys) and 11 in the control group ( 7 girls, 4 boys) in the age group of 5-6 years, attending Prof. Dr. Ayla Oktay Preschool Education Unit at Marmara University Atatürk Faculty of Education in Kadıköy, İstanbul in the spring term of the school year of 20152016. The children in the experimental and control groups have been attending Prof. Dr. Ayla Oktay Preschool Education Unit at Marmara University Atatürk Faculty of Education since age 3. All the parents, except for two mothers, are higher education graduates. Thus, the children in the experimental and control group and their families have homogeneous characteristics.

\section{Data Collection Tool}

The "Scale of Respect for Diversity" developed by Ekmişoğlu (2007) was used in the research. The data were collected with the scale of respect for diversity which was implemented one-to-one before and after the program by the researcher.

Prepared based on a constructivist approach, "Respect for Diversity Program with Family Involvement Developed for the Age Group of 5-6 Years" consists of a total of 52 integrated activities, implemented for 3 days a week. Every integrated activity also contains three gradual activities. The program was planned in a way to be implemented for 14 weeks in total. Because the number of children in the experimental group was 12, Family Involvement Bulletins were prepared for 12 weeks. No planned activity was performed with the families in the 1 st week when the program started and in the 14 th week when the program was terminated. 


\section{The Analysis of the Data}

Non-parametric tests were used in the analysis of the data. The Mann Whitney $U$ test was employed to determine whether there was a difference between the pre-test results of the experimental and control groups. The Wilcoxon Signed Sequence Test was used to compare the pre-test and post-test total scores of the experimental group. The difference between the post-test scores of the experimental and control groups was checked by the Mann-Whitney U test.

\section{Findings}

As a result of the Mann Whitney-U test which was conducted for the purpose of determining whether the pre-test scores of Respect for Diversity Scale significantly varied according to the variable of experimental and control group, it was determined that there was no significant difference between the groups $(\mathrm{z}=-1.112 ; \mathrm{p}>.05)$. As a result of the Mann Whitney-U test which was conducted for the purpose of determining whether the post-test scores of the children significantly varied according to the variable of experimental and control groups, it was determined that there was a significant difference between the groups $(\mathrm{z}=-2.104 ; \mathrm{p}<.05)$. Examining the mean ranks, it was seen that the experimental group obtained higher scores of respect for diversity than the control group. As a result of the Wilcoxon Signed Rank Test which was conducted for the purpose of determining whether there was a significant difference between the pretest-posttest scores obtained by the experimental group from the Scale of Respect for Diversity, it was determined that there was a significant difference $(\mathrm{z}=-2.563 ; \mathrm{p}<.05)$. Considering the mean rank and totals of difference scores, it was seen that the difference was on behalf of positive ranks, in other words post-test scores. As a result of the Wilcoxon Signed Rank Test which was conducted for the purpose of comparing the pretest-posttest scores obtained by the control group from the Scale of Respect for Diversity, it was determined that the scores of respect for diversity did not differ significantly $(\mathrm{z}=-.892 ; \mathrm{p}>.05)$. According to this result, it was determined that the daily education program prepared according to the MEB 2013 Preschool Education Program did not alter the scores of respect for diversity significantly.

\section{Discussion and Concusion}

According to the results of an evaluation which was implemented before the applications of the "Respect for FamilyAttended Diversity Curriculum Developed for the Age Group of 5-6 Years", it was determined that there was no significant difference between the pretest scores of respect for diversity of children in the experimental and control groups. In accordance with this result, it is possible to state that the children in the experimental and control groups had similar scores of respect for diversity before the application. Considering mean rank scores of the children in the experimental and control groups, the children in the experimental group had higher score averages than the children in the control group. This result indicates that the Respect for Family-Attended Diversity Curriculum Developed for the Age Group of 5-6 Years is effective. Examining the relevant literature, it is possible to encounter international curriculums supporting our study. Examining the respect for diversity curriculums, in other words the anti-bias curriculums, it is seen that the respect for diversity curriculum was founded in a book by Ramsey (1987) at the beginning of the 1980s, which was titled "Teaching and Learning in a Diverse World - Multicultural Education for Young Children" and in which he developed the "Multicultural Education Approach". It revealed that multicultural education has risen under the influence of cultural differences and is surrounded by many dimensions. Another researcher, Derman Sparks (1989) developed the Anti-Bias Curriculum, which was based on the themes of bias and discrimination for the first time in the United States, and published his work in a book.

Examining the similar studies which support the findings in this study and have been carried out in our country, it is seen that the study by KEDV (2004) titled "Respect for Cultural Diversity in Early Childhood" is the first project that has ever been implemented in this area. Another study is research by Ekmişoğlu (2007) examining the views of preschool teachers on the concept of respect for diversity. Based on these views, the "Respect for Diversity Scale" was developed. As a result of the study, it was seen that the children did not have sufficient information and experience about the concept of diversity. In addition to these studies, Eren (2015) examined whether there was a difference between the respect for diversity acquisitions of five-year-old children and children receiving and not receiving education based on the storyline method. According to the results of the study, the Ministry of National 
Education (2013) stated that respect for diversity could be fostered in children with the help of daily routine activities of a Preschool Curriculum, as well as education based on the storyline method.

The Respect for Family-Attended Diversity Curriculum which was applied to the children in the experimental group affected their levels of respect for diversity positively. In other words, the "Respect for Family-Attended Diversity Curriculum" is effective in preventing the development of bias and raising awareness of respect for diversity at an early age. In a study exploring the experiences and perspectives of immigrant mothers about early learning for the purpose of determining the basic principles of the learning theories of parents and their anxieties about pedagogic applications at school, it was determined that trainers needed to interact with families so that the parents could contribute to their children by developing an understanding of learning based on cultural capital and games.

In a study by Vanderbroeck (2000), it is suggested that an effective early childhood curriculum can teach children who will encounter diversities throughout their lives how to respect the diversities of people. In addition, May (1999) suggests that enabling children to focus in a way to raise awareness of bias and discrimination with the help of the curriculum will support their respect for diversity and develop their value judgements regarding social justice and integration.

On the grounds of the study results, it is possible to state that the "Respect for Family-Attended Diversity Curriculum Developed for the Age Group of 5-6 Years" affects children's levels of respect for diversity positively. The children who participated in the Respect for Family-Attended Diversity Curriculum had higher levels of respect for diversity than the children to whom the present Ministry of National Education curriculum (2013) was applied, which indicates the effectiveness of the curriculum. According to this result, it is possible to state that the curriculum sets an example in preschool education to remove discrimination that may be encountered between individuals in future years. 


\section{Kaynakça / References}

Aamodt, S. \& Wang, S. (2013). Çocuğunuzun beynine hoş geldiniz. İstanbul: NTV Yayınları.

Aboud, F. E. (1988). Children and prejudice. Oxford: Basil Blackwell.

Akıncı, B., Nergiz, A., ve Gedik, E. (2015). Uyum süreci üzerine bir değerlendirme: Göç ve toplumsal kabul. Gö̧̧ Araştırmaları Dergisi, 1(2), 58-83.

Aktaş Arnas, Y. (2013). Okul öncesi eğitimde aile katılımı. Y. Aktaş Arnas (Ed.), Aile eğitimi ve okul öncesinde aile katılımı içinde (54-61). Ankara: Vize Yayıncılık.

Black-Gutman, D., \& Hickson, F. (1996). The relationship between racial attitudes and social-cognitive development in children: An Australian study. Developmental Psychology, 32(3), 448.

Brinson, S. (2001). Racial attitudes and racial preferences of African American preschool children as related to the ethnic identity of primary caregivers. Contemporary Education, 72(2), 15-21.

Büyüköztürk, Ş. (2007). Deneysel desenler: ön test - son test kontrol grubu desen ve veri analizi (2. baskı). Ankara: Pegem A Yayınc1lik.

Connolly, P., Smith, A. ve Kelly, B. (2009) Ethnic habitus and young children: A case study of Northern Ireland, European Early Childhood Research Journal, 17(2), 217-232.

Creswell, J. W. (2013). Araştırma deseni (Çev. S. B. Demir). Ankara: Eğiten Kitap.

Delice, A. (2010). The sampling 1ssues in quantitative research. Educational Sciences Theory and Practice, 10(4), 2001-2018.

Derman-Sparks, L. \& A.B.C Task Force (1989) Anti-bias curriculum: Tools for empowering young children. Washington : DC; NAEYC.

Doyle, A. B., \& Aboud, F. E. (1995). A longitudinal study of white children's racial prejudice as a social-cognitive development. Merrill-Palmer Quarterly, 41(2), 209-228.

Ekmişoğlu, M. (2007). Erken çocukluk döneminde farklılıklara saygı kavramı hakkında öğretmen görüşlerinin incelenmesi ve farklılıklara saygı ölçeği'nin geçerlik ve güvenirlik çalışması (Yayımlanmamış yüksek lisans tezi). Onsekiz Mart Üniversitesi Sosyal Bilimler Enstitüsü, Çanakkale.

Erdoğan, F. K., ve Baş, S. (2018). Özel gereksinimli birey farkındalığının 4-6 yaş çocuklarına kazandırılması. Yaratıcı Drama Dergisi, 13(1), 101-113.

Eren, S. (2015). Öyküleştirme yöntemine dayalı eğitimin beş yaş çocuklarında farklılıklara saygı kazanımına etkisinin incelenmesi (Yayımlanmamış yüksek lisans tezi). Hacettepe Üniversitesi. Eğitim Bilimleri Enstitüsü. Ankara.

Fantuzzo, J., Butlosky-Shearer, R., McDermott P. A., McWayne, C., Frye, D. \& Perlman, S. (2007). Investigations of social-emotional classroom behavior and school readiness for low-income urban preschool children. School Psychology Review, 36(1), 44-62.

Gürşimşek, I. (2003). Okul öncesi eğitime aile katılımı ve psikososyal gelişim. Kuram ve Uygulamada Eğitim Bilimleri. 3(1), 125-144

KEDV. (2006). Erken çocuklukta farklılıklara saygı eğitimi el kitabı. İstanbul: Derin Yayınları.

MEB. (2013). Milli Ĕgitim Bakanlı̆̆ı Temel Eğitim Genel Müdürlüğü Okul Öncesi Eğitim Programı. Ankara: Devlet Kitapları Müdürlüğü.

May, S. (Ed.). (1999). Critical multiculturalism: Rethinking multicultural and antiracist education. London: Falmer Press.

McWayne, C., Campos, R., \& Owsianik, M. (2008). A multidimensional, multilevel examination of mother and father involvement among culturally diverse Head Start families. Journal of School Psychology, 46(5), 551-573.

Murray, J. (2012). Learning to live together: An exploration and analysis of managing cultural diversity in centrebased early childhood development programmes. Intercultural Education, 23(2), 89-103.

Oktay, A., Gürkan, T., Zembat, R., \& Unutkan, Ö. P. (2006). Ne yapıyorum? neden yapıyorum? nasıl yapmalıyım? İstanbul: YaPa Yayınları.

Özbek, Ö. Y. (2011). 60-72 aylık çocuklara uygulanan aile katılımlı ilköğretime hazırlık programının çocukların ilköğretime hazır bulunuşluk düzeyine etkisi (Yayımlanmamış Yüksek lisans tezi). Marmara Üniversitesi Eğitim Bilimleri Enstitüsü, İstanbul.

Özel, E., Konca, A. S., \& Çağdaş, A. (2016). Investigating parental involvement at beginning of elementary school. Journal of Theory and Practice in Education 12(4), 891-908. 
Özsoy, E., \& Yıldız, G. (2013). Kişilik kavramının örgütler açısından önemi: bir literatür taraması. Işsletme Bilimi Dergisi, 1(2), 1-12.

Öztürk, Ş., Şahin, Ş. \& Mercan, E. (2010). Üniversite öğrencilerinin okul öncesi eğitime ilişkin görüşleri (Ondokuzmayıs Üniversitesi örneği). Ahi Evran Üniversitesi Eğitim Fakültesi Dergisi, 11(1), 175-186

Palmer, G. (1990). Preschool children and race: An Australian study. Australian Journal of Early Childhood, 15(2), 38.

Pelletier, J., \& Brent, J. M. (2002). Parent participation in children'school readiness: The effects of parental selfefficacy, cultural diversity and teacher strategies. International Journal of Early Childhood, 34(1), 45-60.

Polat, Ö. (2007). Çin'i ülke ve kültür olarak 5-6 yaş çocuklarına tanıtan eğitim programının etkisinin deneysel olarak incelenmesi. Marmara Üniversitesi Eğitim Bilimleri Dergisi, 26(26)155-162.

Ramsey, P. G. (1987). Teaching and learning in a diverse world - multiculturel education for young children. New York: Teachers College Pres.

Rosenzweig, J. E. (1998). I have a new friend in me: The effect of multicultural/antibias curriculum on the development of social cognition in preschoolers (Yayımlanmamıs doktora tezi). University of Arizona, USA.

Souto-Manning, M., \& Mitchell, C. H. (2009). The role of action research in fostering culturally-responsive practices in a preschool classroom. Early Childhood Education Journal, 37(4), 269-277. doi:10.1007/s10643-009-0345-9

Topçubaşı, T. (2015). Farklılıklara saygı eğitim programının ögrencilerin farklılıklara saygı düzeyine etkisi (Yayımlanmamış Yüksek lisans tezi). Kocaeli Üniversitesi, Sosyal Bilimler Enstitüsü, Kocaeli.

Üner, E. (2011). Okul öncesi eğitim programındaki 36-72 aylık çocuklara farklılıklara saygı eğitimi kazandırmanın öğretmen görüşleri doğrultusunda değerlendirilmesi (Yayımlanmamış Yüksek lisans tezi). Erciyes Üniversitesi, Kayseri.

Vandenbroeck, M. (2000, Ağustos). Self-awareness, cultural 1dentity and connectedness: three terms to (re)define in anti-bias. Work Paper presented at the Europen Conference on Quality in Early Childhood Education (EECERA) Conference. London, England.

Yahya, R. (2016). Bridging home and school: Understanding immigrant mothers' cultural capital and concerns about play-based learning. Early Years, 36(4), 340-352.

York, S. (2016). Roots and wings: Affirming culture and preventing bias in early childhood. USA: Redleaf Press. 